\title{
Novel serum markers HSP60, CHI3L1, and IGFBP-2 in metastatic colorectal cancer
}

\author{
MICHAL VOCKA ${ }^{1}$, DANIEL LANGER ${ }^{2}$, VLADIMIR FRYBA ${ }^{3}$, JAROMIR PETRTYL $^{4}$, \\ TOMAS HANUS $^{5}$, MARTA KALOUSOVA ${ }^{6}$, TOMAS ZIMA ${ }^{6}$ and LUBOS PETRUZELKA ${ }^{1}$
}

\begin{abstract}
${ }^{1}$ Department of Oncology, First Faculty of Medicine, Charles University, and General University Hospital in Prague, 12808 Prague 2; ${ }^{2}$ Surgery Department, Second Faculty of Medicine, Charles University, and Military University Hospital in Prague, 16902 Prague $6 ;{ }^{3}$ First Department of Surgery, Department of Abdominal, Thoracic Surgery and Traumatology, First Faculty of Medicine, Charles University, and General University Hospital in Prague; ${ }^{4}$ Fourth Department of Internal Medicine, Department of Gastroenterology and Hepatology; ${ }^{5}$ Department of Urology;

${ }^{6}$ Institute of Medical Biochemistry and Laboratory Diagnostics, First Faculty of Medicine, Charles University, and General University Hospital in Prague, 12808 Prague 2, Czech Republic
\end{abstract}

Received December 2, 2018; Accepted July 12, 2019

DOI: $10.3892 / 01.2019 .10925$

\begin{abstract}
Colorectal cancer (CRC) is the second leading tumor diagnosis in women and men in the Czech Republic. Patient outcome depends on tumor stage at the time of diagnosis and, in metastatic disease, on the localization and extent of distant metastases. The early detection of metastatic liver disease is an important indication for liver surgery. Therefore, novel biomarkers are urgently required. Serum samples were collected from 97 patients with histologically confirmed metastatic CRC at the time of diagnosis or at the time of progression during palliative treatment, and 79 samples from healthy controls. All patients exhibited adequate liver and renal function and signed informed consent was obtained from all patients included in the current study. The serum levels of Heat shock protein 60 (HSP60), Chitinase-3-like protein 1 (CHI3L1) and Insulin-like growth factor binding protein 2 (IGFBP-2) were measured using immunochemistry. The serum levels of HSP60, CHI3L1 and IGFBP-2 were significantly higher in patients with CRC compared with healthy controls. When compared with carcinoembryonic antigen (CEA), HSP60 exhibited the same sensitivity and specificity, while CHI3L1 and IGFBP-2 exhibited decreased sensitivity. Additionally, the serum levels of HSP60 and IGFBP-2 were indicated to be correlated with the presence of liver metastases, which is in contrast to CEA
\end{abstract}

Correspondence to: Dr Michal Vocka, Department of Oncology, First Faculty of Medicine, Charles University, and General University Hospital in Prague, U Nemocnice 499/2, 12808 Prague 2, Czech Republic

E-mail: michal.vocka@vfn.cz

Key words: heat shock protein 60, chitinase-3-like protein 1, insulin-like growth factor binding protein 2, colorectal cancer, serum biomarker, survival and Cancer antigen 19-9 (CA19-9). Patients with higher HSP60 and IGFBP-2 levels exhibited a significantly worse survival $(\mathrm{P}<0.001$ and 0.007 , respectively). The results of the current study indicate HSP60 to be an effective biomarker in patients with metastatic CRC, with it exhibiting an equal sensitivity to CEA. Additionally, HSP60 and IGFBP-2 levels also strongly correlated with extension of liver metastases and exhibited a prognostic value that contrasted that of CEA.

\section{Introduction}

Colorectal cancer (CRC) is the third most common cancer in men $(1,006,000$ cases, $10.6 \%$ of the total) and the second in women $(795,000$ cases, $9.2 \%$ of the total) worldwide (1). $\mathrm{CRC}$ is the second leading tumor diagnosis in women and in men in the Czech Republic (2). Patient outcome strongly depends on the stage of tumor at the time of diagnosis and, in metastatic disease, the prognosis depends on localization and extent of distant metastases (3). Early detection and diagnosis still present the best chance for successful treatment and improved outcome. Early detection of metastatic liver disease is important for indication of liver surgery. Therefore, novel biomarkers for early cancer detection and early detection of metastatic disease are strongly needed.

Heat shock protein 60 (HSP60) belongs to a functional superfamily which is highly conserved during evolution and play important roles in protein folding and translocation $(4,5)$. Hsp60 can be considered as a protein with moonlighting functions (6). Abnormalities in expression level have been detected from different diseased tissues including inflammatory diseases and various cancers. The HSP60 acts as an autoantigen in the development of a range of autoimmune diseases including Hashimoto's thyroiditis (7), inflammatory bowel diseases (8) and chronic obstructive pulmonary diseases (9). HSP60 is also implicated in the cell survival and apoptosis signaling pathways (10). An increased level of HSP60 has been detected in colon cancer $(11,12)$, breast cancer (13), 
prostate (14) and others. In patients with CRC HSP60 levels have been correlated with tumor grade and stage and with occurrence of lymph node metastases (15).

A few studies have suggested that circulating Hsp60 protein level has potential value in early detection of CRC $(12,16)$ Serum levels in patients with CRC were compared to standard serum tumor markers by Hamelin et al (16), but the majority of studied patients had localized CRC (only 36 patients with distant metastasis).

Chitinase-3-like protein 1 (CHI3L1) also known as YKL-40, is a highly conserved glycoprotein produced by cancer cells (including CRC cells), macrophages and neutrophils and by fetal and embryonic stem cells (17-19). CHI3L1 regulates VEGF and plays an important role in angiogenesis (19-21) and inflammation $(17,22)$, including inflammation-associated carcinogenic changes of colonic epithelial cells $(23,24)$. Furthermore, YKL-40 participates in the activation of Akt signaling pathways in these cells (25), in cell proliferation and differentiation $(18,19)$, and in apoptosis (26). Serum concentration of CHI3L1 is emerging as a new biomarker in patients with CRC $(17,27)$ High serum CHI3L1 levels from the general population are associated with an increased risk of development $(27,28)$ and death from gastrointestinal cancer (29). In addition, high serum CHI3L1 levels before and after operation for CRC are independent prognostic biomarkers of short overall survival (30-32).

IGFBP-2 is an extracellular protein that binds IGF-2 and, with a smaller affinity, IGF-1 (33). Tumor growth is assisted by various growth factors, and insulin-like growth factors (IGF-1 and IGF-2) are among the most important $(34,35)$. They stimulate cell proliferation, regulate differentiation, and prevent apoptosis. A majority of the IGFs are bound to IGFBPs. Their release is dependent on the rate of IGFBP proteolysis and may also induce IGF-independent effects after interaction with specific cell membrane structures $(36,37)$. IGFBP-3 is the principal binding protein in healthy persons, but in patients with CRC the expression of IGFBP-2 may become dominant (38). Activation of the type 1 receptor (IGF-1R) by binding of IGFs is the key point in triggering intracellular metabolic and mitogenic mechanisms. IGFs are recognized as mitogens for colon mucosa (39). IGFBP-2 plays an important role in heat shock protein 27-mediated cancer progression and metastasis (40). IGFBP-2 serum levels are significantly elevated in patients with prostate cancer (41), colon cancer $(28,42,43)$, lung cancer $(44)$ and others.

In the present study, we investigated the serum levels of HSP60, CHI3L1 and IGFBP-2 in patients with metastatic CRC compared to healthy controls. This is the first study that compares the levels of these markers to standard biomarkers used in the monitoring of CRC (CEA and cancer antigen 19-9 (CA19-9)) and that also studies the correlation of tumor characteristics and treatment outcomes to the serum levels of HSP60, CHI3L1 and IGFBP-2.

\section{Materials and methods}

Patients and healthy control characteristics. Between November 2011 and May 2013, 97 patients with metastatic CRC and 79 relatively age- and gender matched healthy individuals were enrolled in this study. Serum samples were collected before beginning treatment for $\mathrm{mCRC}(\mathrm{n}=52)$ or at the time of progression during palliative treatment for $\mathrm{mCRC}$ $(\mathrm{n}=45)$. The majority of patients were after resection of primary tumour (79.4\%). In the control group 79 healthy controls after negative colonoscopy were included $(45.6 \%$ women, median age 62 years). Table I shows the characteristics of the patients and healthy controls.

All patients and controls had adequate liver and renal function (transaminases $<2 \mathrm{x}$ and creatinine clearance $<1,5 \mathrm{x}$ upper normal limit) and signed informed consent.

In the cancer group the serum levels of CEA and CA19-9 (median (25-75\% percentile); $\mathrm{N}=97$ ) were 26.1 (4.3-82.9) ug/1 and 25.2 (9.95-372.8) kIU/1, respectively. Both markers were significantly elevated compared to the control group $(\mathrm{N}=79)$, difference was counted by Mann-Whitney $\mathrm{U}$ test $(\mathrm{P}<0.001$; $\mathrm{P}=0.006$, respectively) (45).

Laboratory analyses. Blood for laboratory analyses was collected after overnight fasting via puncture of the cubital vein simultaneously with blood collection for routine examinations. Routine biochemical parameters were measured in fresh samples. For special parameters, blood was standardly centrifuged for $10 \mathrm{~min}$ at 3,000 rpm (rotations per minute) and serum was stored at $-80^{\circ} \mathrm{C}$ until analysis. Levels of HSP60 (StressMarq Biosciences), CHI3L1 (R\&D Systems) and IGFBP-2 (Mediagnost) in serum samples were determined by commercially available ELISA (enzyme linked immunoassay) kits according to the manufacturer's protocols. The intraassay (or interassay) coefficient of variation (CV) was always less than $10 \%$. Concentrations of CEA and CA19-9 in serum samples were determined by chemiluminiscent immunoanalysis (Architect, Abbott, USA).

Statistical analysis. Statistical analysis was performed using SAS (SAS Institute Inc., Cary, NC, USA). Basic statistics were calculated for parameters measured in the whole group and in different groups and subgroups. Selected statistical data were also graphically processed via Box \& Whisker plot diagrams. A non-parametric analysis of variance Mann-Whitney U test was used for comparison of the distribution of the individual parameters in the different groups and subgroups [median (25-75\% percentile)] and a Kruskal-Wallis test followed by Mann Whitney U with Bonferroni's correction was used in case of comparing 3 subgroups. Due to non-Gaussian distribution of variables Spearman's correlation coefficient was used to determine the dependency of characters. Statistical significance was determined at the border of alpha $=0.05$. Receiver operating characteristic (ROC) curves were generated to assess the diagnostic accuracy of each parameter; the sensitivity and specificity of optimum cut off point were found. Overall survival was defined as the interval between serum collection and death or the last follow-up.

\section{Results}

Baseline characteristic of patients and controls. In the cancer group serum 97 patients with generalized CRC were included (38.1\% women, median age 64 years). The most common site of metastases was liver in $66.0 \%$ and lung in $32.0 \%$ patients. In the control group 79 healthy controls after negative colonoscopy were included (45.6 women, median age 62 years). 
Table I. Basic characteristics of patients and healthy controls.

\begin{tabular}{|c|c|c|}
\hline Characteristics & $\begin{array}{l}\text { Cancer group } \\
\qquad(\mathrm{N}=97)\end{array}$ & $\begin{array}{l}\text { Control group } \\
\qquad(\mathrm{N}=79)\end{array}$ \\
\hline \multicolumn{3}{|l|}{ Age } \\
\hline Median & 64.4 & 61.5 \\
\hline$<50$ & $13(13.4 \%)$ & $24(30.1 \%)$ \\
\hline$>50$ & $84(86.6 \%)$ & $55(69.6 \%)$ \\
\hline \multicolumn{3}{|l|}{ Sex } \\
\hline Male & $60(61.9 \%)$ & $43(54.4 \%)$ \\
\hline Female & $37(38.1 \%)$ & $36(45.6 \%)$ \\
\hline \multicolumn{3}{|l|}{ Histological type } \\
\hline Adenocarcinoma & $91(93.8 \%)$ & - \\
\hline Mucinous carcinoma & $6(6.2 \%)$ & - \\
\hline \multicolumn{3}{|l|}{ Primary site } \\
\hline $\begin{array}{l}\text { Right colon (caecum, } \\
\text { ascendens, transversum) }\end{array}$ & $20(20.6 \%)$ & - \\
\hline $\begin{array}{l}\text { Left colon (descendens, } \\
\text { sigmoideum,rectosigma) }\end{array}$ & $50(51.5 \%)$ & - \\
\hline Rectum & $27(27.9 \%)$ & - \\
\hline \multicolumn{3}{|l|}{ Side of metastasis } \\
\hline Liver & $64(66.0 \%)$ & - \\
\hline Lung & $31(32.0 \%)$ & - \\
\hline Peritoneal & $14(14.4 \%)$ & - \\
\hline Lymphatic nodules & $22(22.7 \%)$ & - \\
\hline \multicolumn{3}{|l|}{$\begin{array}{l}\text { Number of metastatic } \\
\text { sides }\end{array}$} \\
\hline 1 & $57(58.7)$ & - \\
\hline 2 & $28(28.9)$ & \\
\hline 3 or more & $12(12.4)$ & - \\
\hline $\begin{array}{l}\text { Number of previous } \\
\text { treatment line }\end{array}$ & & - \\
\hline 0 & $52(53.6)$ & - \\
\hline 1 & $26(26.8)$ & - \\
\hline 2 & 19 (19.6) & - \\
\hline
\end{tabular}

Serum levels of HSP60, CHI3L1 and IGFBP-2. The serum level of HSP60 in the cancer group was significantly increased compared to healthy controls [mean was 0.51 (25-75\% percentile $0.34-0.86) \mathrm{ng} / \mathrm{ml}$ and $0.25(0.18-0.34) \mathrm{ng} / \mathrm{ml}$, respectively, $\mathrm{P}<0.001$, Fig. 1A]. In the control group there was no significant difference in HSP60 levels between men and women $(\mathrm{P}=0.844)$, but there was significant difference in younger than or equal to 55 years $[\mathrm{N}=24,0.20(0.15-0.30) \mathrm{ng} / \mathrm{ml}]$ and older than $55[\mathrm{~N}=55 ; 0.27(0.22-0.35) \mathrm{ng} / \mathrm{ml} ; \mathrm{P}=0.021]$. Compared to the same aged group with CRC there was significant difference, $\mathrm{P}<0.001$ and $<0.001$, respectively. In the cancer group there was no significant difference in serum level of HSP60 between sex, age and part of colon with primary tumor (Table II). Insinuate difference $(\mathrm{P}=0.084)$ was found between good or moderately and poorly differentiated tumors. No statistically significant differences were found between good or moderately $(\mathrm{N}=75)$ and poorly differentiated tumors $(\mathrm{N}=22, \mathrm{P}=0.309)$ and patients with liver metastases $(\mathrm{N}=64)$ and those without $(\mathrm{N}=33$;
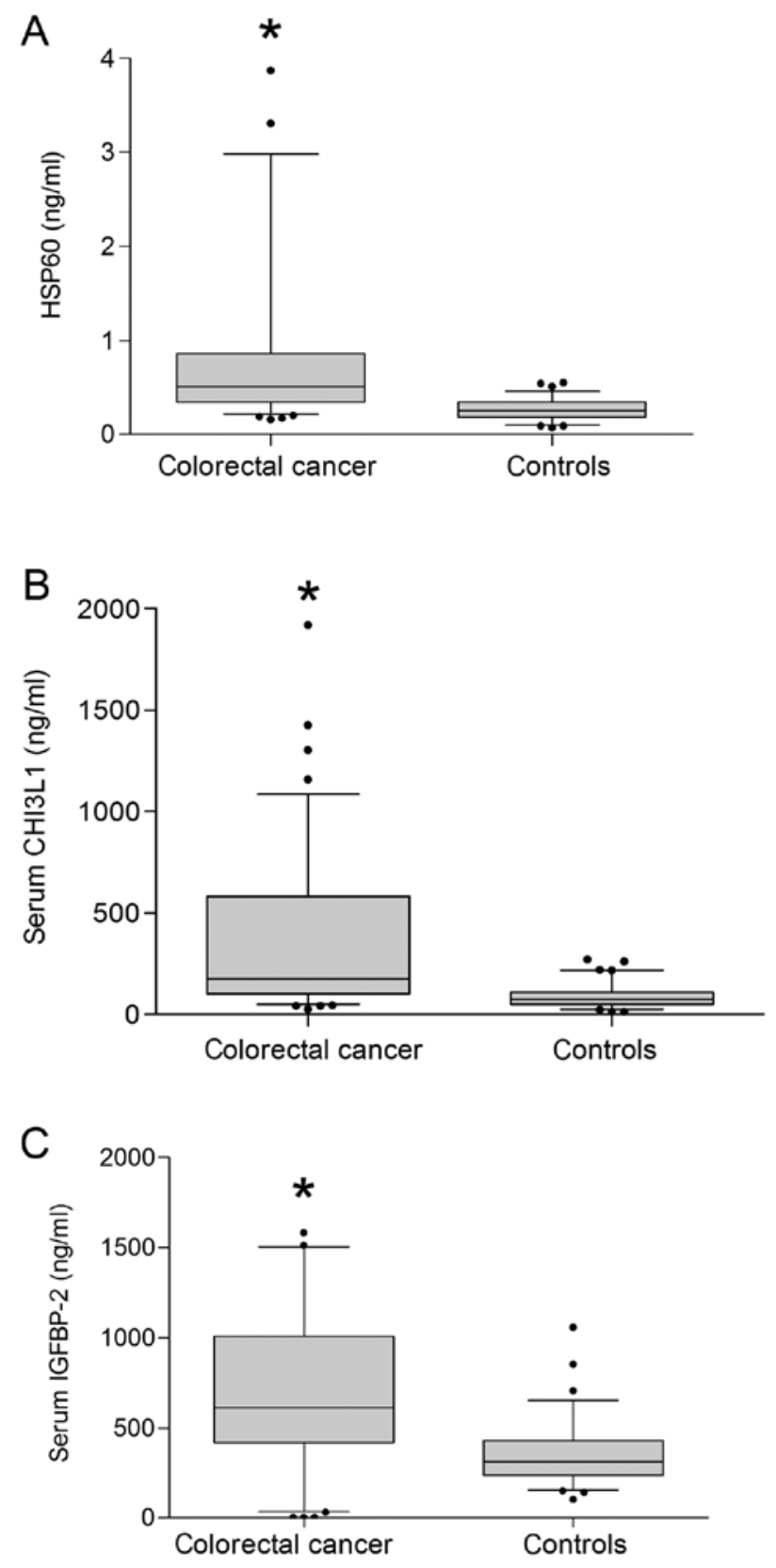

Figure 1. Comparison of HSP60, CHI3L1 and IGFBP-2 levels in patients with CRC and healthy controls. Differences were calculated using a Mann-Whitney U test. (A) HSP60 levels, (B) CHI3L1 levels and (C) IGFBP-2 levels. ${ }^{*} \mathrm{P}<0.0001$ vs. healthy controls. HSP60, heat shock protein 60 ; CHI3L1, chitinase-3-like protein 1; IGFBP-2, insulin-like growth factor binding protein 2 ; CRC, colorectal cancer.

$\mathrm{P}=0.217)$. Positive association was found between patients with non-resected primary tumor $(\mathrm{N}=20)$ and patients after resection $(\mathrm{N}=77 ; \mathrm{P}=0.039)$ Negative association was identified between patients with and without pulmonary metastases $[0.42$ (0.25-0.63) ng/l, N=31; 0.52 (0.37-1.22) ng/ml, N=66; $\mathrm{P}=0.010]$.

The serum level of CHI3L1 in the cancer group was 177.0 (102.0-582.0) $\mathrm{ng} / \mathrm{ml}$ and was significantly elevated compared to $76.0(50.0-109.0) \mathrm{ng} / \mathrm{ml}$ in the healthy control group (Fig. 1B, $\mathrm{P}<0.001)$. In the control group, there was no significant difference in CHI3L1 levels between men and women $(\mathrm{P}=0.927)$, between younger than or equal to 55 years $(\mathrm{N}=24)$ and older than $55(\mathrm{~N}=55 ; \mathrm{P}=0.108)$. In the cancer group there was no 


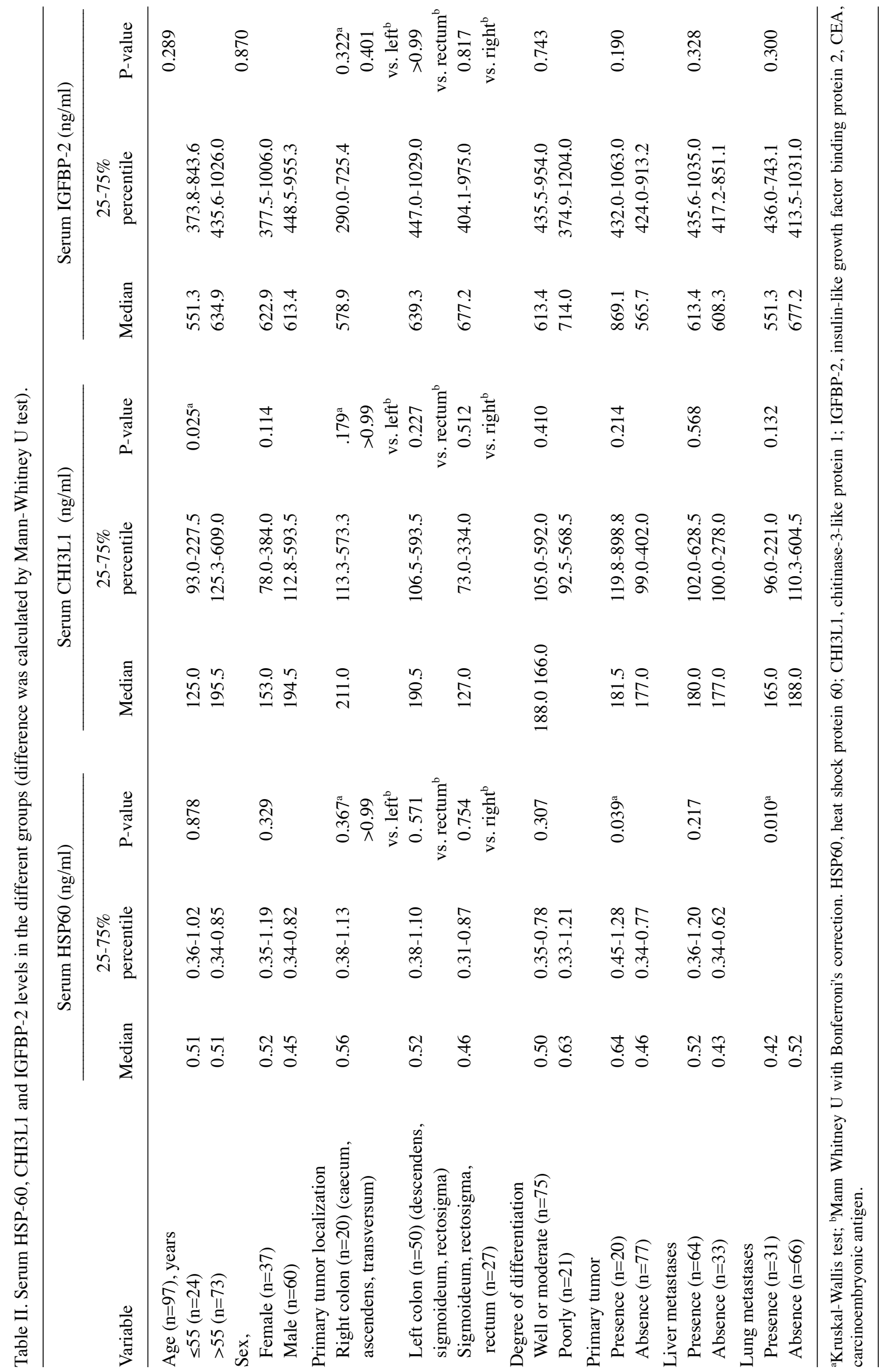



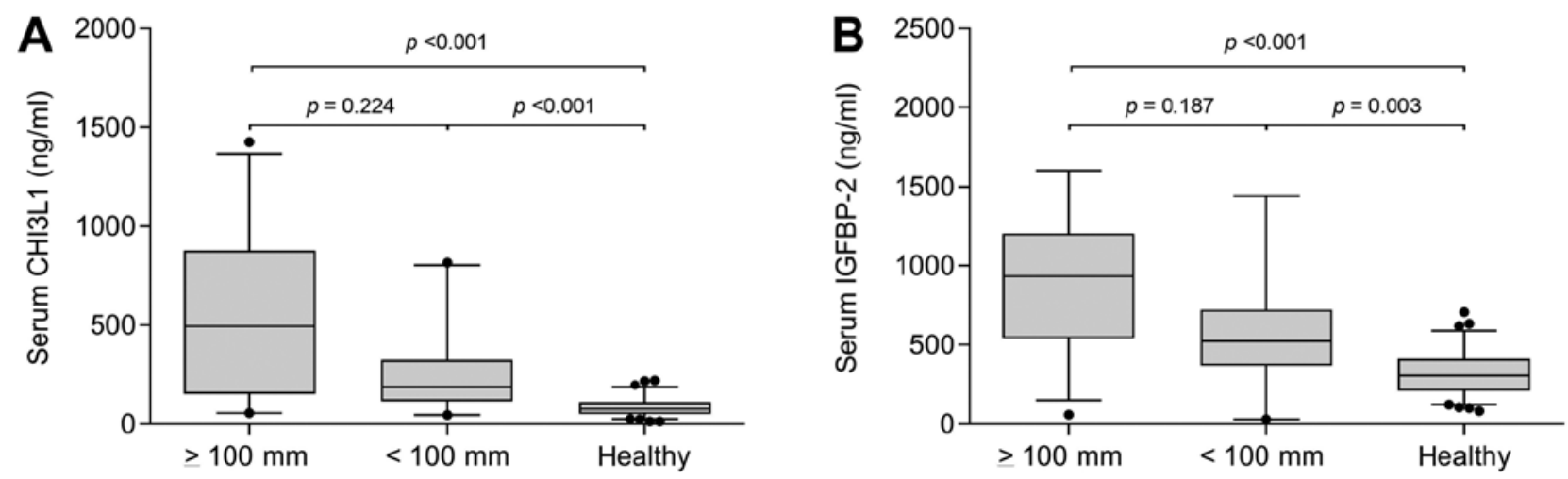

Figure 2. Serum levels of CHI3L1 and IGFBP-2 in patients without pulmonary and with liver metastasis. Differences were calculated using a Mann Whitney U with Bonferroni's correction test. (A) CHI3L1 and (B) IGFBP-2 levels in patients with liver metastases $\geq 100 \mathrm{~mm},<100 \mathrm{~mm}$ and healthy controls. CHI3L1, chitinase-3-like protein 1; IGFBP-2, insulin-like growth factor binding protein 2.

significant difference in CHI3L1 levels between men and women $(\mathrm{P}=0.114)$, but there was significant difference in younger than or equal to 55 years $(\mathrm{P}=0.025$, Table $\mathrm{I})$.

In the cancer group, there was no significant difference between part of colon with primary tumor, tumor grade and presence or absence of the primary tumor. No statistically significant differences between patients with liver metastases were found $(\mathrm{P}=0.568)$. There was indicated difference in presence or absence of pulmonary metastases $(\mathrm{P}=0.132)$. The group of patients with liver metastases without pulmonary metastases was divided into patients with the sum of the longest dimension of liver metastases smaller than 100 millimeters $(\mathrm{N}=20)$, larger than or equal to 100 millimeters $(\mathrm{N}=29)$ and control group $(\mathrm{N}=79)$. The difference in CHI3L1 levels was statistically significant $(\mathrm{P}<0.001$ by Kruskal-Wallis test), $496.0(136.5-876.0) \mathrm{mg} / \mathrm{ml}, 188.0(111.0-293.0) \mathrm{mg} / \mathrm{ml}$ and 76.0 (51.0-109.0), respectively (Fig. 2A).

The serum level of IGFBP-2 in the cancer group was $613.4(427.9-968.6) \mathrm{ng} / \mathrm{ml}$ and was significantly elevated compared to $308.1(219.6-417.8) \mathrm{ng} / \mathrm{ml}$ in the healthy control group (Fig. 1C, $\mathrm{P}<0.001$ ). In the control group there was no significant difference in IGFBP-2 levels between men and women $(\mathrm{P}=0.486)$, between younger than or equal to 55 years $(\mathrm{N}=24)$ and older than $55(\mathrm{~N}=55 ; \mathrm{P}=0.189)$. Compared to the same aged group with CRC there were significant differences, $\mathrm{P}<0.001$ and $<0.001$, respectively.

In the cancer group there were no significant differences between sex, age, part of colon with primary tumor and tumor grade (Table I). There was a slight but non-statistically significant difference between presence or absence of primary tumor, $869.1(432.0-1063.0) \mathrm{ng} / \mathrm{ml}(\mathrm{N}=28)$ and 565.7 (424.0-913.2) ng/l $(\mathrm{N}=69)$ respectively $(\mathrm{P}=0.190)$. No statistically significant differences between patients with and without liver metastases $(\mathrm{P}=0.328)$ and with and without pulmonary metastases $(\mathrm{P}=0.300)$.

The group of patients with liver metastases without pulmonary metastases was divided into patients with the sum of the longest dimension of liver metastases smaller than 100 millimeters $(\mathrm{N}=20)$ and larger than or equal to 100 millimeters $(\mathrm{N}=29)$. and control group $(\mathrm{N}=79)$. The difference in CHI3L1 levels was statistically significant $(\mathrm{P}<0.001$ by Kruskal-Wallis test), 935.5 (542.1-1204.0) ng/ml,
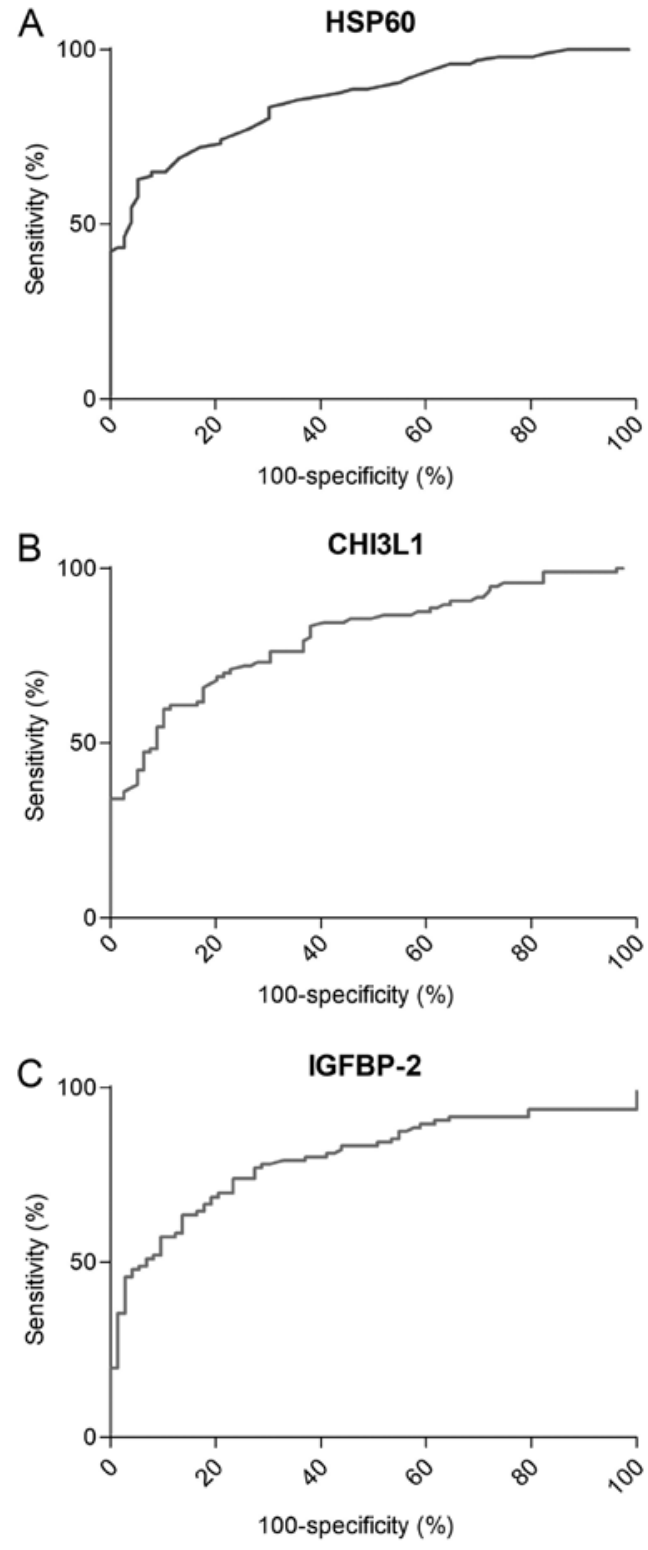

Figure 3. Receiver operator curve analysis of HSP60, CHI3L1 and IGFBP-2. The sensitivity and specificity of (A) HSP60, (B) CHI3L1 and (C) IGFBP-2 to distinguish CRC from healthy controls. HSP60, heat shock protein 60 ; CHI3L1, chitinase-3-like protein 1; IGFBP-2, insulin-like growth factor binding protein 2; $\mathrm{CRC}$, colorectal cancer. 

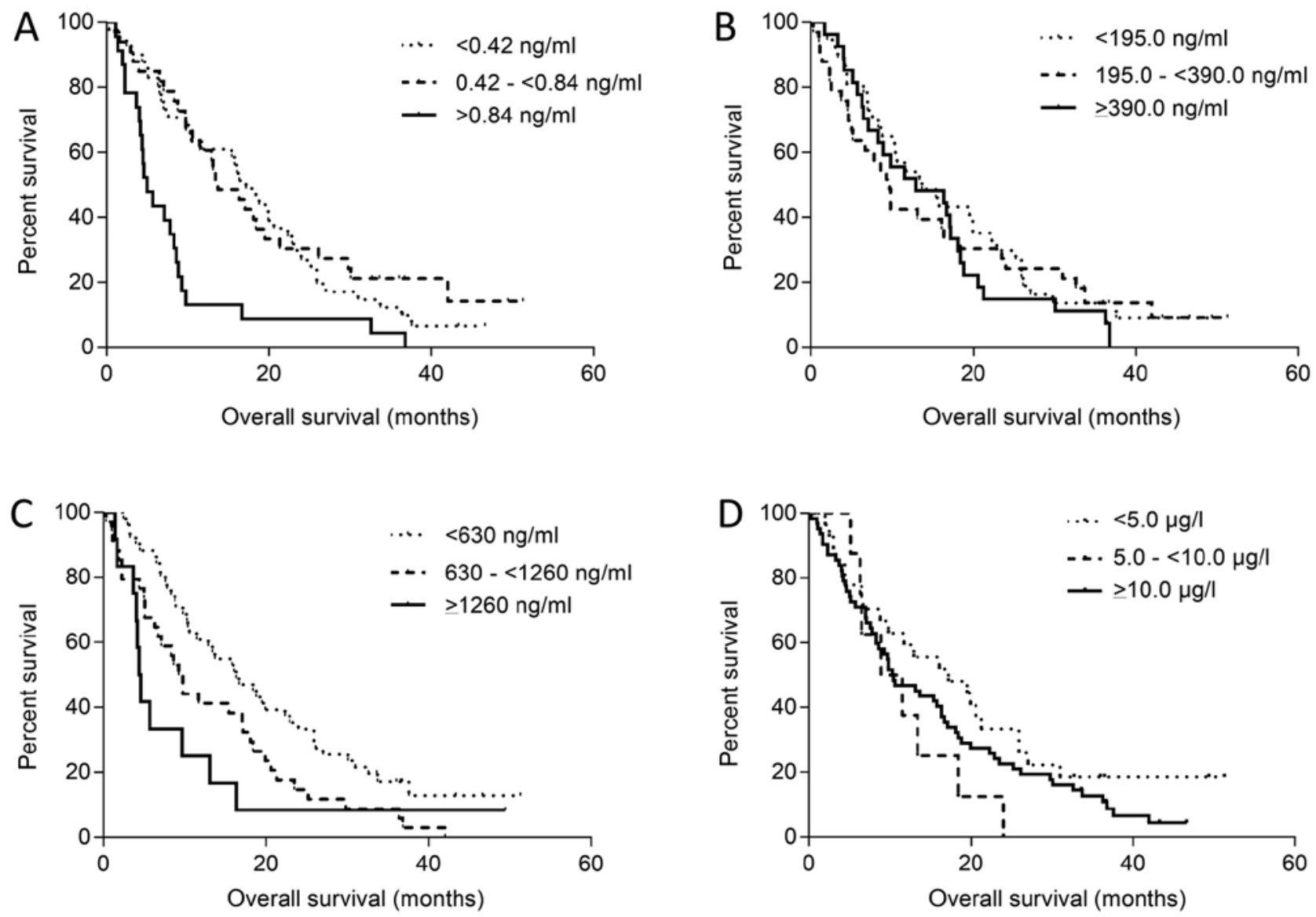

Figure 4. Overall survival according to HSP60, CHI3L1, IGFBP-2 and CEA levels. Kaplan-Meier curves. Difference between curves was calculated by log-rank test. Kaplan-Meier curves of patient (A) HSPp60, (B) CHI3L1, (C) IGFBP-2 and (D) CEA levels. HSP60, heat shock protein 60; CHI3L1, chitinase-3-like protein 1; IGFBP-2, insulin-like growth factor binding protein 2; CEA, carcinoembryonic antigen.

$522.5(368.6-722.0) \mathrm{ng} / \mathrm{ml}$ and $307.0(207.0-411.8)$, respectively (Fig. 2B).

Sensitivity and specificity of HSP60, CHI3L1 and IGFBP-2. ROC curve analysis showed that serum HSP60 with an AUC of 0.856 (Fig. 3A) and serum level cut-off values of $0.42 \mathrm{ng} / \mathrm{ml}$ has the sensitivity and specificity to distinguish CRC from healthy controls at a rate of 62.89 and $94.74 \%$, respectively $(\mathrm{P}<0.001)$. CHI3L1 with an AUC of 0.808 (Fig. 3B) and serum level cut-off values of $195.0 \mathrm{ng} / \mathrm{ml}$ has a sensitivity and specificity rate of 47.42 and $93.67 \%$, respectively $(\mathrm{P}<0.001)$. IGFBP-2 with an AUC of 0.798 (Fig. 3C) and serum level cut-off values of $630.0 \mathrm{ng} / \mathrm{ml}$ has a sensitivity and specificity rate of 48.96 and $94.52 \%$, respectively $(\mathrm{P}<0.001)$.

The level of HSP60, CHI3L1, IGFBP-2 and CEA as prognostic factor. The serum level of HSP60 and IGFBP-2 appears to have a prognostic value. The cut-off for serum HSP60 level was determined as $0.42 \mathrm{ng} / \mathrm{ml}$. Patients were divided into groups with negative serum levels of HSP60 $(<0.42 \mathrm{ng} / \mathrm{ml}$, $\mathrm{N}=41)$, slight increase ( 0.42 and $\leq 0.84 \mathrm{ng} / \mathrm{ml}, \mathrm{N}=33)$ and large increase $(\geq 0.84 \mathrm{ng} / \mathrm{ml}, \mathrm{N}=23)$. From all 97 patients overall survival (OS, time from first sample collection to death) was calculated. No significant differences $(\mathrm{P}=0.610)$ between groups with negative HSP60 levels (mOS 17.2 months) and groups with slight increase (mOS 13.7 months) were observed.
But there were statistically significant differences between the groups with negative (mOS 17.2 months) and large increase of HSP60 serum levels (mOS 5.0 months, P<0.001; Fig. 4A).

The cut-off for serum CHI3L1 level was determined as $195.0 \mathrm{ng} / \mathrm{ml}$. Patients were divided into groups with negative serum levels of HSP60 $(<195.0 \mathrm{ng} / \mathrm{ml}, \mathrm{N}=37)$, slight increase (195.0 and $<390.0 \mathrm{ng} / \mathrm{ml}, \mathrm{N}=27)$ and large increase (>390.0 ng/ml, $\mathrm{N}=33)$. No significant differences $(\mathrm{P}=0.284)$ between the groups with negative CHI3L1 levels (mOS 13.7 months) and with slight increase (mOS 12.9 months) were observed nor between the groups with negative (mOS 13.7 months) and large increase of CHI3L1 serum levels (mOS 9.7 months, $\mathrm{P}=0.680$; Fig. 4B).

The cut-off for serum IGFBP-2 level was determined as $630.0 \mathrm{ng} / \mathrm{ml}$. Patients were divided into groups with negative serum levels of IGFBP-2 $(<630.0 \mathrm{ng} / \mathrm{ml}, \mathrm{N}=51)$, slight increase $(630.0$ and $<1,260.0 \mathrm{ng} / \mathrm{ml}, \mathrm{N}=34)$ and large increase $(\geq 1,260.0 \mathrm{ng} / \mathrm{ml}, \mathrm{N}=12)$. A statistically significant difference $(\mathrm{P}=0.012)$ between the groups with negative HSP60 levels (mOS 16.4 months) and with slight increase (mOS 9.6 months) was observed. There was also a statistically significant difference between the groups with negative (mOS 16.4 months) and large increase of IGFBP-2 serum levels (mOS 4.5 months, $\mathrm{P}=0.007$; Fig. 4C).

The cut-off level for serum CEA was determined as $5.0 \mathrm{ug} / \mathrm{l}$. Patients were divided into groups with negative 
serum levels of CEA $(<5.0 \mathrm{ng} / \mathrm{ml}, \mathrm{N}=27)$, slight increase $(5.0$ and $<10.0 \mathrm{ng} / \mathrm{ml}, \mathrm{N}=8)$ and large increase $(\geq 10.0 \mathrm{ng} / \mathrm{ml}$, $\mathrm{N}=62)$. No significant differences $(\mathrm{P}=0.089)$ between the groups with negative HSP60 levels (mOS 17.2 months) and slight increase (mOS 10.2 months) were observed, nor between the groups with negative (mOS 17.2 months) and large increase of CEA serum levels (mOS 10.4 months, $\mathrm{P}=0.199$; Fig. 4D).

\section{Discussion}

Early diagnosis is crucial for successful treatment even in metastatic CRC with liver involvement. Therefore, new biological markers for early detection (more sensitive and specific than CEA and CA19-9) and predictors of prognosis for CRC are urgently needed in clinical practice.

HSP60 is a key factor involved in inflammation, and serum HSP60 levels might also be increased in patients with inflammatory pathologies such as Crohn's disease and ulcerative colitis (46). Only one previous study has evaluated the application of HSP60 in the diagnosis and prognosis of CRC. Hamelin et al published results from 152 patients with localized CRC and 130 healthy controls. HSP60 AUC was 0.7, which was identical to CEA in this group. They suggested that levels are higher in stage IV compared to I-III, but there is no information about the number of samples in each stage (16). Our data show similar results of sensitivity and specificity compared to CEA (AUC 0.856, and 0.905 respectively) in patients with metastatic disease. These results suggested that serum HSP60 could be a useful biomarker in CRC. In addition, we present a strong correlation between HSP60 and patient survival.

CHI3L1 (Chitinase 3-like 1, YKL-40), a highly conserved glycoprotein produced by cancer cells (including CRC cells), seems to be a new biomarker in patients with cancer $(16,26)$. High serum CHI3L1 levels among the general population are associated with an increased risk of development $(27,28)$ and death from gastrointestinal cancer (29). In addition, high serum CHI3L1 levels before and after operation for CRC are independent prognostic biomarkers of short overall survival (30-32). There is only limited data for metastatic CRC. CHI3L1 levels are different in patients with CRC compared to healthy controls, but sensitivity is not better than CEA. On the contrary, CHI3L1 levels correlate with extent of liver involvement in cases without pulmonary metastases. A difference between overall survival in patients with higher levels of CHI3L1 compared to lower levels was not observed.

IGFBP-2 is an extracellular protein that binds IGF-2 and, with a smaller affinity, IGF-1 (33) IGFBP-2 plays an important role in heat shock protein 27-mediated cancer progression and metastasis (39). IGFBP-2 serum levels were reported as significantly elevated in patients with colon cancer in three studies. Liou et al, presented data from 162 patients before surgery for CRC with a sensitivity rate of $80.2 \%$ and specificity rate of $64.0 \%$. Higher levels of IGFBP-2 were associated with an increased risk of mortality (38). Renehan et al, showed data of 92 patients with CRC, but only 29 with distant metastasis. They reported correlation of serum levels with tumor size and sensitivity in metastatic disease at a rate of 55\% with specificity at a rate of $92 \%$ (42). Kushlinski et al, showed data for 95 patients, but only 17 with mCRC colon cancer patients overall (43).
Our cohort shows the same sensitivity and specificity as previously reported studies. Additionally, our data show statistically significant correlation between serum levels and extent of liver involvement. The entry level of IGFBP-2 appears to be a prognostic factor that strongly correlates with overall survival. This can be partially explained by the strong correlation of both markers with liver involvement in patients without pulmonary metastases. Patients with a sum of liver metastases larger than $100 \mathrm{~mm}$ had higher levels of IGFBP-2 and their liver reserve was smaller. Another partial explanation could be that patients with non-resected primary tumor, who have higher levels of IGFBP-2, were not operated on because of their worse performance status, thereby possibly being a reason for the worse outcome of the treatment.

On the other hand, we are aware of the limited number of patients investigated in this study. Further investigation and data are needed to clarify these promising results on a larger cohort of patients.

Our data indicated that serum HSP60 could be used as an effective biomarker for the detection of distant metastasis with the same sensitivity as CEA and better sensitivity than CA19-9. Serum IGFBP-2 has a smaller sensitivity than CEA and a similar one to CA19-9. HSP60 and IGFBP-2 may play an important role in promoting CRC progression and dissemination. HSP60 and IGFBP-2 levels correlate with extension of liver involvement in patients without pulmonary metastases, who are the candidates for a curative liver resection. The entry level of HSP60 and IGFBP-2 appears to be a prognostic factor that correlates with overall survival.

\section{Acknowledgements}

Not applicable.

\section{Funding}

The present study was supported by research projects from the Ministry of Industry and Trade if the Czech Republic (grant no. TIP FR-TI3/666), Charles University (Czech Republic; grant no. Progres Q25) and the Ministry of Health (Czech Republic; grant no. DRO VFN64165).

\section{Availability of data and materials}

The datasets used and analysed for the present study are available from the corresponding author upon reasonable request.

\section{Authors' contributions}

MV, LP, MK, TH, TZ and JP conceived and designed the study. MV, DL, VF and JP recruited patients and obtained samples. MK performed the laboratory analyses. MV, DL, LP, JP and VF analysed and interpreted the data, and wrote the manuscript. MK, TH, TZ, JP and VF revised the paper. All authors read and approved the final manuscript.

\section{Ethics approval and consent to participate}

The study protocol conformed to the Declaration of Helsinki, and was approved by the Institutional Ethics Committee of 
First Faculty of Medicine of Charles University in Prague (Czech Republic). Each participating patient had provided signed written informed consent.

\section{Patient consent for publication}

Consent was obtained for the publication of patient data.

\section{Competing interests}

The authors declare that they have no competing interests.

\section{References}

1. Bray F, Ferlay J, Soerjomataram I, Siegel RL, Torre LA and Jemal A: Global cancer statistics 2018: GLOBOCAN estimates of incidence and mortality worldwide for 36 cancers in 185 countries. CA Cancer J Clin 68: 394-424, 2018.

2. Dusek L, Muzik J, Maluskova D, Májek O, Pavlik T, Koptíková J, Melichar B, Büchler T, Fínek J, Cibula D, et al: Cancer incidence and mortality in the Czech Republic. Klin Onkol 27: 406-423, 2014.

3. O'Connell JB, Maggard MA and Ko CY: Colon cancer survival rates with the new american joint committee on cancer sixth edition staging. J Natl Cancer Inst 96: 1420-1425, 2004.

4. Hendrick JP and Hartl FU: Molecular chaperone functions of heat-shock proteins. Annu Rev Biochem 62: 349-384, 1993.

5. Pockley AG: Heat shock proteins, inflammation, and cardiovascular disease. Circulation 105: 1012-1017, 2002.

6. Henderson B, Fares MA and Lund PA: Chaperonin 60: A paradoxical, evolutionarily conserved protein family with multiple moonlighting functions. Biol Rev Camb Philos Soc 88: 955-987, 2013.

7. Marino Gammazza A, Rizzo M, Citarrella R, Rappa F, Campanella C, Bucchieri F, Patti A, Nikolic D, Cabibi D, Amico G, et al: Elevated blood Hsp60, its structural similarities and cross-reactivity with thyroid molecules, and its presence on the plasma membrane of oncocytes point to the chaperonin as an immunopathogenic factor in hashimoto's thyroiditis. Cell Stress Chaperones 19: 343-353, 2014.

8. Tomasello G, Rodolico V, Zerilli M, Martorana A, Bucchieri F, Pitruzzella A, Marino Gammazza A, David S, Rappa F, Zummo G, et al: Changes in immunohistochemical levels and subcellular localization after therapy and correlation and colocalization with CD68 suggest a pathogenetic role of Hsp60 in ulcerative colitis. Appl Immunohistochem Mol Morphol 19: 552-561, 2011.

9. Cappello F, Caramori G, Campanella C, Vicari C, Gnemmi I, Zanini A, Spanevello A, Capelli A, La Rocca G, Anzalone R, et al: Convergent sets of data from in vivo and in vitro methods point to an active role of Hsp60 in chronic obstructive pulmonary disease pathogenesis. PLoS One 6: e28200, 2011.

10. Czarnecka AM, Campanella C, Zummo G and Cappello F: Mitochondrial chaperones in cancer: From molecular biology to clinical diagnostics. Cancer Biol Ther 5: 714-720, 2006.

11. Cappello F, Bellafiore M, Palma A, David S, Marcianò V, Bartolotta T, Sciumè C, Modica G, Farina F, Zummo G and Bucchieri F: 60KDa chaperonin (Hsp60) is over-expressed during colorectal carcinogenesis. Eur J Histochem 47: 105-110, 2003.

12. He Y, Wu Y, Mou Z, Li W, Zou L, Fu T, Zhang A, Xiang D, $\mathrm{Xiao} \mathrm{H}$ and Wang $\mathrm{X}$ : Proteomics-based identification of HSP60 as a tumor-associated antigen in colorectal cancer. Proteomics Clin Appl 1: 336-342, 2007.

13. Bini L, Magi B, Marzocchi B, Arcuri F, Tripodi S, Cintorino M, Sanchez JC, Frutiger S, Hughes G, Pallini V, et al: Protein expression profiles in human breast ductal carcinoma and histologically normal issue. Electrophoresis 18: 2832-2841, 1997.

14. Castilla C, Congregado B, Conde JM, Medina R, Torrubia FJ, Japón MA and Sáez C: Immunohistochemical expression of Hsp60 correlates with tumor progression and hormone resistance in prostate cancer. Urology 76: 1017.e1-e6, 2010.

15. Cappello F, David S, Rappa F, Bucchieri F, Marasà L, Bartolotta TE, Farina F and Zummo G: The expression of HSP60 and HSP10 in large bowel carcinomas with lymph node metastase. BMC Cancer 5: 139, 2005.
16. Hamelin C, Cornut E, Poirier F, Sylvie Pons S, Beaulieu C, Charrier JP, Haïdous H, Cotte E, Lambert C, Piard F, et al: Identification and verification of heat shock protein 60 as a potential serum marker for colorectal cancer. FEBS J 278: 4845-4859, 2011

17. Johansen JS, Schultz NA and Jensen BV: Plasma YKL-40: A potential new cancer biomarker? Future Oncol 5: 1065-1083, 2009.

18. Johansen JS, Høyer PE, Larsen LA, Price PA and Møllgård K: YKL-40 protein expression in the early developing human musculoskeletal system. J Histochem Cytochem 55: 1213-1228, 2007.

19. Brøchner CB, Johansen JS, Larsen LA, Bak M, Mikkelsen HB, Byskov AG, Andersen CY and Møllgård K: YKL-40 is differentially expressed in human embryonic stem cells and in cell progeny of the three germ layers. J Histochem Cytochem 60: 188-204, 2012.

20. Faibish M, Francescone R, Bentley B, Yan W and Shao R: A YKL-40 neutralizing antibody blocks tumor angiogenesis and progression: A potential therapeutic agent in cancers. Mol Cancer Ther 10: 742-751, 2011.

21. Shao R: YKL-40 acts as an angiogenic factor to promote tumor angiogenesis. Front Physiol 4: 122, 2013.

22. Lee CG, Da Silva C, Dela Cruz CS, Ahangari F, Ma B, Kang MJ, He CH, Takyar S and Elias JA: Role of chitin and chitinase/chitinase-like proteins in inflammation, tissue remodelling, and injury. Annu Rev Physiol 2011; 73: 479-501, 2011.

23. Kawada M, Seno H, Kanada K, Nakanishi Y, Akitake R, Komekado H, Kawada K, Sakai Y, Mizoguchi E and Chiba T: Chitinase 3-like-1 promotes macrophage recruitment and angiogenesis in colorectal cancer. Oncogene 31: 3111-3123, 2012.

24. Eurich K, Segawa M, Toei-Shimizu S and Mizoguchi E: Potential role of chitinase 3-like-1 in inflammation-associated carcinogenic changes of epithelial cells. World J Gastroenterol 15: 5249-5259, 2009.

25. Chen CC, Llado V, Eurich K, Tran HT and Mizoguchi E: Carbohydrate-binding motif in chitinase 3 -like 1 (CHI3L1/YKL-40) specifically activates akt signaling pathway in colonic epithelial cells. Clin Immunol 140: 268-275, 2011.

26. Lee CG, Hartl D, Lee GR, Koller B, Matsuura H, Da Silva CA, Sohn MH, Cohn L, Homer RJ, Kozhich AA, et al: Role of breast regression protein 39 (BRP-39)/Chitinase 3-like-1 in Th2 and IL-13-induced tissue responses and apoptosis. J Exp Med 206: 1149-1166, 2009

27. Johansen JS, Christensen IJ, Jørgensen LN, Olsen J, Rahr HB, Nielsen KT, Lurberg S, Brünner N and Nielsen HJ: Serum YKL-40 in risk assessment for colorectal cancer: A prospective study of 4,496 subjects at risk of colorectal cancer. Cancer Epidemiol Biomarkers Prev 24: 621-626, 2015.

28. Johansen JS, Bojesen SE, Mylin AK, Frikke-Schmidt R, Price PA and Nordestgaard BG: Elevated plasma YKL-40 predicts increased risk of gastrointestinal cancer and decreased survival after any cancer diagnosis in the general population. J Clin Oncol 27: 572-578, 2009.

29. Johansen JS, Bojesen SE, Tybjærg-Hansen A, Mylin AK, Price PA and Nordestgaard BG: Plasma YKL-40 and total and disease-specific mortality in the general population. Clin Chem 56: 1580-1591, 2010.

30. Cintin C, Johansen JS, Christensen IJ, Price PA, Sørensen S and Nielsen HJ: High serum YKL-40 level after surgery for colorectal carcinoma is related to short survival. Cancer 95: 267-274, 2002.

31. Cintin C, Johansen JS, Christensen IJ, Price PA, Sørensen S and Nielsen HJ: Serum YKL-40 and colorectal cancer. Br J Cancer 79: 1494-1499, 1999.

32. Liu X, Zhang Y, Zhu Z, Ha M and Wang Y: Elevated pretreatment serum concentration of YKL-40: An independent prognostic biomarker for poor survival in patients with colorectal cancer. Med Oncol 31: 85, 2014.

33. Clemmons DR: Insulin-like growth factor binding proteins and their role in controlling IGF actions. Cytokine Growth Factor Rev 8: 45-62, 1997.

34. Yu H and Rohan T: Role of the insulin-like growth factor family in cancer development and progression. J Natl Cancer Inst 92: 1472-1489, 2000.

35. Pollak MN, Schernhammer ES and Hankinson E: Insulin-like growth factors and neoplasia. Nat Rev Cancer 4: 505-518, 2004.

36. Schütt BS, Langkamp M, Rauschnabel U, Ranke MB and Elmlinger MW: Integrin-mediated action of insulin-like growth factor binding protein-2 in tumor cells. J Mol Endocrinol 32: $859-868,2004$ 
37. Jogie-Brahim S, Feldman D and Oh Y: Unraveling insulin-like growth factor binding protein-3 actions in human disease. Endocr Rev 30: 417-437, 2009.

38. Liou JM, Shun CT, Liang JT, Chiu HM, Chen MJ, Chen CC, Wang HP, Wu MS and Lin JT: Plasma insulin-like growth factor-binding protein-2 levels as diagnostic and prognostic biomarkers of colorectal cancer. J Clin Endocrinol Metab 95: $1717-1725,2010$

39. Schoen RE, Tangen CM, Kuller LH, Burke GL, Cushman M, Tracy RP, Dobs A and Savage PJ: Increased blood glucose and insulin, body size, and incident colorectal cancer. J Natl Cancer Inst 91: 1147-1154, 1999.

40. Hung CS, Huang CY, Lee CH, Chen WY, Huang MT, Wei PL and Chang YJ: IGFBP2 plays an important role in heat shock protein 27-mediated cancer progression and metastasis. Oncotarget 8: 54978-54992, 2017

41. Cohen P, Peehl DM, Stamey TA, Wilson KF, Clemmons DR and Rosenfeld RG: Elevated levels of insulin-like growth factor-binding protein-2 in the serum of prostate cancer patients. J Clin Endocrinol Metab 76: 1031-1035, 1993.
42. Renehan AG, Jones J, Potten CS, Shalet SM and O'Dwyer ST: Elevated serum insulin-like growth factor (IGF)-II and IGF binding protein-2 in patients with colorectal cancer. $\mathrm{Br}$ J Cancer 83: 1344-1350, 2000.

43. Kushlinskii NE, Gershtein ES, Nikolaev AA, Delektorskaya VV, Korotkova EA, Dvorova EA and Kostyleva OI: Insulin-like growth factors (IGF), IGF-binding proteins (IGFBP), and vascular endothelial growth factor (VEGF) in blood serum of patients with colorectal cancer. Bull Exp Biol Med 156: 684-688, 2014.

44. Lee DY, Kim SJ and Lee YC: Serum insulin-like growth factor (IGF)-I and IGF-binding proteins in lung cancer patients. J Korean Med Sci 14: 401-404, 1999.

45. Vocka M, Langer D, Petrtyl J, Vockova P, Hanus T, Kalousova M, Zima T and Petruzelka L: Trefoil factor family (TFF) proteins as potential serum biomarkers in patients with metastatic colorectal cancer. Neoplasma 62: 470-477, 2015.

46. Rodolico V, Tomasello G, Zerilli M, Martorana A, Pitruzzella A, Gammazza AM,David S,Zummo G,Damiani P, Accomando S, et al: Hsp60 and Hsp10 increase in colon mucosa of Crohn's disease and ulcerative colitis. Cell Stress Chaperones 15: 877-884, 2015. 